\title{
A VILÁGJÁRVÁNY FORMÁLTA TURIZMUS TRENDEK ÉS A HAZAI FEJLESZTÉSI POLITIKA VÁRHATÓ HATÁSAI DÉL- BARANYA TURIZMUSÁRA
}

\author{
Szabó Géza \\ habilitált egyetemi docens, tanszékvezetö PTE TTK FFI Turizmus Tanszék; \\ fg4t@gamma.ttk.pte.hu \\ DOI: 10.15170/TVT.2022.07.01.05.
}

\begin{abstract}
Aubert Antal pályatárssal, kollégával, kutatótárssal és baráttal a 90-es évek eleji megismerkedésünk óta számos kutatásban vizsgáltuk tágabb (Dél-Dunántúl) (CSAPÓ AUBERT - SZABÓ 2015, SZABÓ - AUBERT 2012, AUBERT - MARTON - SZABÓ 2011, AUBERT et al. 2010, AUBERT - SZABÓ 2007) és szükebb életterünk (Baranya) (AUBERT - SZABÓ 2005, AUBERT - MISZLER - SZABÓ 2000, AUBERT - SZABÓ 1999) geográfiai, turisztikai jellemzőit. Kutatásaink és közös publikációink területi súlypontja egyértelműen Baranya, tematikájukat tekintve pedig a turizmus területi dimenzióit, annak rurális kérdésköreit feltáró munkák születtek vizsgálatainkból (AUBERT et al. 2018a,b, AUBERT - SZABÓ 2008, SZABÓ - AUBERT 2005, AUBERT - SZABÓ 1993). Most köszöntőként arra a területre kalauzolnám az ünnepeltet és a kedves olvasót, ami mindig is kiemeltnek számított nálunk: DélBaranya, Villány, Siklós, Harkány és a Drávamente vidéke.
\end{abstract}

\begin{abstract}
Absztrakt
A Dél-Baranya Határmenti Települések Egyesülete az általa lefedett térség adottságaiból és meglévő turisztikai pozíciójából kiindulva az idegenforgalomra, mint a térség fejlesztésének meghatározó szakterületére koncentrál. Az egyesület hatókörébe 88 település tartozik a Villányi-hegységtől a Dráváig terjedő térségben, ami területileg lefedi Dél-Baranyát.

A 2019-es turisztikai „sikerévet” követő pandémia válság erősen hatott a dél-baranyai térség turizmusára is. A pandémia első, második és harmadik hullámai és az azok megfékezését szolgáló karantén intézkedések teljesen ellehetetlenítették a turizmust. A nagy visszaesések és a járványhullámok közötti kereslet élénkülések nyomán már érzékelhetők a turizmus nemzetközi dimenzióiban is olyan változások, amelyek térségre is hatással lehetnek, valamint a hazai 2020-as és 2021-es tapasztalatok is a tanulságok levonására ösztönöznek a közeljövő és a távolabbi - remélhetően pandémiamentes - időszak turisztikai fejlödését, fejlesztéseit illetően. Ebben a gondolkodásban a turisztikai keresleti és kínálati trendek szükségszerü, de nehezen meghatározható változásai és a hazai fejlesztéspolitika által kijelölt stratégiai irányok is determináns tényezőkként veendők figyelembe.
\end{abstract}

Kulcsszavak: pandémia hatásai, turisztikai trendek, fejlesztéspolitika, Dél-Baranya 


\title{
THE IMPACT OF TOURISM TRENDS INFLUENCED BY THE PANDEMIC AND OF HUNGARIAN DEVELOPMENT POLICY ON THE TOURISM SECTOR OF SOUTH BARANYA
}

\begin{abstract}
The Association of the South Baranya Municipalities concentrates, starting from the endowments and the existing tourism positions of its competency area, tourism as a dominant activity for the development of the area. The competency area of the Association covers a total of 88 settlements ranging from the Villány Mountain to the Dráva River, e.g. South Baranya geographically.

The pandemic crisis following the "peak" year of 2019 had a serious impact on the tourism sector of South Baranya as well. The first, second and third wave of the pandemic and the quarantine measures aiming at the easement of the problems stopped tourism completely. As an effect of the increased demand in between the great declines and pandemic waves, some changes in international tourism are now palpable that may also impact the respective geographical area; also, the experiences of domestic tourism from 2020 and 2021 allow us to draw some conclusions concerning the tourism processes and development of the near and more remote future - hopefully free from pandemic. In this approach, the necessary but hardly identifiable changes in the trends of tourism demand and supply, and the strategic directions set by the Hungarian development policy must all be taken into consideration as determining factors.
\end{abstract}

Keywords: impacts of the pandemic, tourism trends, development policy, South Baranya 


\section{Bevezető}

A Dél-Baranya Határmenti Települések Egyesülete az általa lefedett térség adottságaiból és meglévő turisztikai pozíciójából kiindulva az idegenforgalomra, mint a térség fejlesztésének meghatározó szakterületére koncentrál. Az egyesület a térségbe érkező vidékfejlesztési források felhasználásában is prioritást szánt a turizmusnak, különösen annak a nagy centrumokon, turisztikai gócterületeken kívüli, azokat kiegészítő szerepkörü fogadóterületeinek.

A 2019-es turisztikai „sikerévet”, vagy ahogyan ma nevezik a turizmus berkeiben, az „utolsó békeévet" követő pandémia válság erősen hatott a dél-baranyai térség turizmusára is. DélBaranya követte a nemzetközi és hazai forgalmi fejleményeket, az eddig még nem tapasztalt visszaesést, a vendégforgalom közel 1,5 éves teljes leállását. A 2020. év nyári időszaka és a 2021-es év nyara csak kivételt erösítő példaként említhető, amikor a forgalom újra kezdett visszatérni a korábbi nagyságrendhez. De azt sem szabad elfelejteni 2021 Öszét elhagyva, hogy az elmúlt év nyári fellendülése után késő ősszel újra egy teljes visszaesés következett be a COVID-19 járvány 2. és 3. hulláma miatt. Így bizony nem kizárt, hogy a 2021-es szezon biztató koranyári és nyári fokozódó forgalmát is követheti a járvány 4 . hullámának elbizonytalanító hatása.

Akár az is kimondható, hogy „hullámközi” állapotban voltunk 2021 nyarán. De már érzékelhetök a turizmus nemzetközi dimenzióiban olyan változások, amelyek a térségre is hatással lehetnek, valamint a hazai 2020-as és 2021-es tapasztalatok is a tanulságok levonására ösztönöznek a közeljövő és a távolabbi - remélhetően pandémia mentes - időszak turisztikai fejlődését, fejlesztéseit illetően. A pandémia okozta kihívásra válaszolni próbált a hazai fejlesztéspolitika is, megalkotva a 2017-ben elfogadott Nemzeti Turizmusfejlesztési Stratégia (NTS 2030 ${ }^{16}$ ) frissítését Turizmus 2.0 címmel. Ezzel összefüggésben a kormány 2020. év őszén újradefiniálta a turizmusfejlesztés preferált területeit, a turisztikai térségeket ${ }^{17}$. Ezek száma 11re emelkedett, köztük a Pécs-Villány turisztikai térséggel, amelynek jelentős turisztikai vonzású települései közé Dél-Baranyából is többen beletartoznak.

A dél-baranyai térség turisztikai jövőképét egyaránt meghatározzák a nemzetközi turizmus érzékelhető kínálati és keresleti trendjei és ezek hazai megjelenése. Mindezek kiegészülnek az elmúlt két - több szempontból csonka - szezon magyarországi tapasztalataival. A turisztikai jövőképben pedig hangsúlyos szerepet játszanak a hazai, szakági fejlesztéspolitika térséget is érintő elképzelései. A fentebb vázolt tematika alapján tekintenénk át - szándékunk szerint - a térségre is vonatkoztatva a globális, nemzetközi és hazai változásokat és ezek várható hatásait.

\section{A pandémia hatása a nemzetközi és a hazai turizmusra}

A COVID-19 kódjelü vírus 2019-végi vuhani, kínai feltünését követően 2020. március 11-én nyilvánította világjárvánnyá a kialakult helyzetet a WHO. A pandémia európai megjelenése 2020-év február végére tehető, amikor Ausztria tiroli sírégiójában és Észak-Olaszországban tömeges, gócszerü megbetegedések történtek. Erre reagálva az illetékes kormányok lezárásokkal, karantén intézkedésekkel próbálták fékezni a járványt. A korlátozó intézkedések között elsőként a nemzetközi légiforgalom leállítása, a határforgalom korlátozása, majd teljes zárása és az otthonelhagyás korlátozásai szerepeltek. Mindegyik intézkedés súlyosan hatott elsőként a nemzetközi, majd a hazai turizmusra is. Visszatekintve kimondható, hogy a turizmus addigi - szinte - megtörés nélküli forgalmi bővülése nem csak nemzetközi, hanem a belföldi dimenziókban is súlyos sérüléseket szenvedett. A Turisztikai Világszervezet (UNWTO) adatai szerint, a nemzetközi turistaérkezések 2019-ben még 1400 millió feletti értéke 2020-ra közel 1

\footnotetext{
${ }^{1}$ https://mtu.gov.hu/cikkek/strategia

17 429/2020. (IX. 14.) számú kormányrendelet a turisztikai térségek meghatározásáról
} 
milliárd turistaérkezéssel, 73\%-kal csökkent. Ez súlyos csapást jelentett minden nemzetközi tekintetben is számottevő desztinációnak. Jól mutatja a kialakult helyzet komolyságát az 1. ábra adatsora. A járvány kitörését követő lezárások miatt 2020 februárjától minden hónapban komoly 70-90\%-os forgalmi visszaesést regisztrált a Turisztikai Világszervezet a kiinduló évnek számító 2019. év hónapjaihoz képest. Ez még a korlátozások enyhülésével meglóduló nyári forgalomban is 76-79\%-al maradt el a korábbi volumentől. A kutatások a járvány okozta válsághelyzet kettősségére hívták fel a figyelmet (KOVÁCS et al. 2021). A turizmus szektort mind az egészségügyi, mind pedig a gazdasági hatások súlyosan érintették.

1. ábra: A nemzetközi turistaérkezések számának visszaesése 2020-ban és 2021 elején a 2019es havi adatokkal összehasonlítva

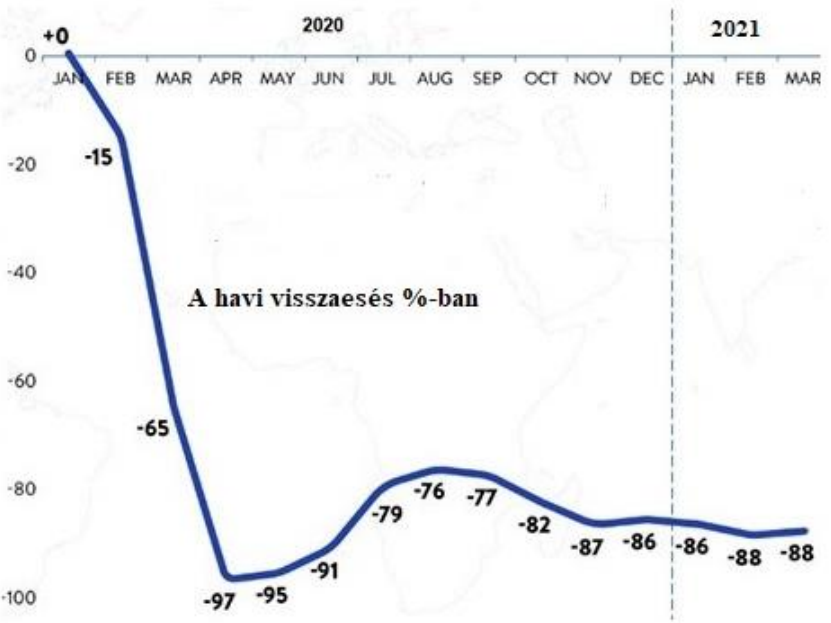

Forrás: http://www.unwto.org/news/tourist-numbers-down-83-but-confidence-slowly-rising

Magyarország turizmusának vendégéjszakákban mért forgalma 2019-ben erősen megközelítette a 43 millió vendégéjszakát (kereskedelmi és az egyéb szálláshelyek összesített forgalmát tekintve), amelynek több, mint 50\%-a a külföldi vendégkör forgalmából származott. Ez a szegmens zuhant vissza 73\%-kal az Magyar Turisztika Ügynökség (a továbbiakban: MTÜ) adatai szerint 2020-ban. A legsúlyosabban Budapestet érintette a visszaesés, hiszen a főváros forgalmának több mint 90\%-át még a külföldiek hozták 2019-ben. A jóval kisebb forgalmú Dél-Dunántúlon, amely régió a hazai kiemelt desztinációk között a középmezőny végén foglalt helyet, a külföldi vendégéjszakák száma még a 20\%-ot sem érte el a „békeévekben”, így a visszaesés is szerényebben érintette.

Nagyon súlyos volt a 2. ábrán látható módon a belföldi forgalom 2020. évi visszaesése, sőt teljes megszünése a korlátozások tavaszi időszakában. Bár a 2020. év nyarára a belföldi forgalom újra felerösödött - és ez a Dél-Dunántúlt is kedvezően érintette -, az elveszett külföldi volument ez sem pótolhatta. Jól látható a 2. ábrán, hogy a 2020. őszén beköszöntő második hulláma a pandémiának - és az ezt tompítani próbáló lezárások - a jól induló nyári szezon végét, az őszi utószezont bel- és külföldi turisták vonatkozásában egyaránt tönkretették. 
2. ábra ${ }^{18}$ : A kül- és belföldi vendégforgalom havi alakulása 2019-ben és 2020-ban

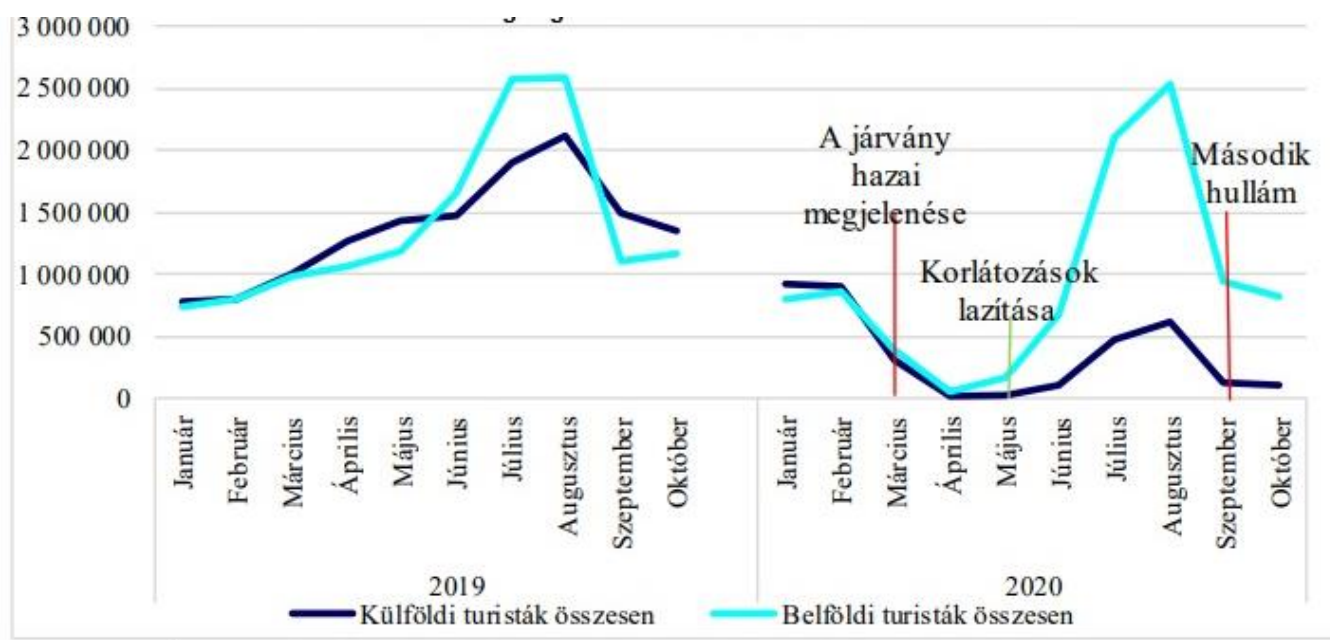

Forrás: ÁSZ jelentés 2021.

A hazai turisztikai régiók közül az egyik legkisebb arányban külföldieket vonzó a DélDunántúl. A pandémia előtti évben az Állami Számvevőszék jelentése ${ }^{3}$ szerint a külföldiek 197 ezer vendégéjszakát realizáltak a régióban. 2020-ban a külföldi vendégéjszakák száma 59 ezerre csökkent, ami csak a Tisza-tó értékét előzte meg ebben a válságos évben. A régiónk belföldi vendégforgalma 2019-ben januártól-októberig 895 ezer vendégéjszakát hozott, ami a pandémia évének azonos időszakában 643 ezerre csökkent. Ez a visszaesés az egyik legjelentősebb volt a hazai régiók között. Tehát az adatok alapján kimondhatjuk, hogy a DélDunántúl volt az a turisztikai régió, amelyik a leginkább megszenvedte a járvány hatásait 2020 ban. Ebből nem volt kivétel a Pécs-Villány turisztikai térség sem, amely az MTÜ adatai szerint a 11 turisztikai térség teljes belföldi vendégforgalmából csupán 4\%-kal részesedve csak a 7 . helyet szerezte meg a rangsorban.

Napjainkban ugyan még a pandémia hullámai között vergődik a turizmus, ám már elképzelések születtek a válságból való kilábalásra. A fő kérdés, hogy miként fog kilábalni a világturizmus és természetesen az egyes desztinációk vendégforgalma a válságból. Az elméletileg lehetséges kilábalási forgatókönyveket a közgazdászok a járványkezelés egészségügyi és gazdasági intézkedéseinek eredőjeként, a várható GDP alakulásához kapcsolják (MCKINSEY \& COMPANY, 2020). A kilábalási pályákat képletesen betük formálta függvény típusokhoz hasonlítják (POSGAY et al., 2020). A típusok között van V; W; L; U, vagy éppen pipa $\square$, jelezve a GDP várható, vagy remélt alakulását. Erre analógiaként tekintve, párhuzamba állítható a turizmus forgalmának és a bevételeinek a prognosztizált alakulásával.

Így beszélnek „V” jellegü kilábalásról, ahol a lezárásokat követő gyors és megrendítő mélységü visszaesést követően azonnal „visszapattan” a mélypontról a turizmus és elérve a korábbi szintjét, minden megy tovább a megszokott úton. Bár a vendégek vágyaiban benne van ez a verzió, ám az elmúlt másfél év és benne a két lazítási időszak nem igazolta ezeket az elvárásokat. Ugyan 2020 nyarán a járvány enyhülésével beinduló szolgáltatások iránt megnövekedett az igény, ám ez jórészt csak a belföldre és néhány biztonságosabbnak vélt vidéki helyszínre, pl. a Balaton és a vidéki wellness központok egy részére korlátozódott. Hasonlókat tapasztalhattunk 2021 nyarán is.

A „W” jellegü fejlődés inkább közelebb van a valósághoz, hiszen a 2020. nyári fellendülést követően újra bezárkózás és visszaesés, majd 2021. késő tavaszától beinduló forgalom némi

\footnotetext{
${ }^{18}$ Állami Számvevőszék elemzése: A turizmus helyzete - a járvány előtt és alatt file://C:/Users/Otthon/Downloads/turizmus_jarvany20210325.pdf
} 
reményt adott a turizmus-vendéglátás szektornak. Reményt adott, de egyben illúziókat is rombolt, amelyek még a piac gyors visszarendeződésében reménykedtek.

Az „L” alakú fejlödési pálya úgy értelmezhető, hogy a pandémia következtében lezuhanó forgalom sokáig nem tér magához. Első szakaszában még a járványügyi korlátozások jelentik a gátját a fejlődésnek, de később kiegészülnek a forgalmi korlátok a bezárt és gazdasági, vagy munkaerő gondok miatt ki sem nyíló vendéglátó és szálláshelyek kihasználatlan kapacitásaival. Országosan nézve ez a modell írja le Budapest nagyon beszúkült külföldi vendégforgalmát.

Az „L” alakú fejlődési pálya kedvezőbb variánsaként értelmezhető az „U” görbe, ami esetünkben azt jelentené. hogy az erőteljes visszaesés követően az adott desztináció csak nehezen tér vissza a fejlődési pályára, a forgalom hosszú hónapokon át a minimális szinten stagnál. Ám ezt követően gyors fejlődéssel zárkóznak fel a forgalmi adatok a korábbi szinthez. Ez a modell tükröztethető leginkább a hazai vidéki wellness központok belföldi forgalmára.

A pipa $\square$ modell úgy értelmezhető, hogy a katasztrofális visszaesés után a forgalom csak lassan tér vissza a korábbi szintre. Ez a fejlődési pálya kevésbé elhúzódó válságot feltételez, mint az „L” formátum, de itt is lassú a kilábalás és nem tudni, hogy visszatérnek-e még a válság előtti idők? A közgazdász elemzők a 2008-as válság tapasztalatait összegezve a GDP növekedés szempontjából a pipa modellt látják a legvalószínübbnek (POSGAY et al. 2019).

Mind a négy modell vonatkoztatható a hazai és azon belül a dél-baranyai turizmusra is, a tanulságai azonban túlmutatnak desztinációnk határain!

\section{Keresleti és kínálati trendek, valamint a turisták attitüdjének változásai a világjárvány hatására}

A turizmus és vendéglátás válságát hozó pandémia jelentős hatást fejtett ki a turisták keresleti szokásaira és az utazással kapcsolatos hozzáállására (attitüdjére) is. Ezek a változások a korábbi keresleti trendeket sem hagyták érintetlenül és valószínüleg meghatározzák a „kilábalás”, a járvány utáni időszak keresleti jellemzőit is. Széles körben válogatva a turizmus és a vendéglátás trendjei között, súlypontok határozhatók meg, olyan tematikai egységek, amelyek több, erre a kérdéskörre irányuló kutatásban is feltüntek. A német autóklub (ADAC), az egyik legnagyobb ilyen jellegü szervezet, a világon külön figyelmet szentelt a pandémia hatásainak a vizsgálatára a turizmus és a vendégek utazási kedvének szempontjából ${ }^{19}$. Ezen kívül a nemzetközi szaksajtó számos elemzést, értékelést készített a témakörben, amelyeket felhasználtunk az összefoglalóban.

Fontos megemlíteni az elemzéshez használt források tekintetében, hogy a pandémia teljesen váratlanul érte a turizmus szakmát és a turizmus tervezésén, fejlesztésén munkálkodókat egyaránt. A forgalom teljes leállására még nem volt példa a modern turizmus történetében, ilyen esetre nem voltak szcenáriók elökészítve. Még benne vagyunk a pandémia okozta válságban, így a helyzet leírására és a perspektívák, trendek felvázolása is még csak részleges elképzelések, szakmai publikációk ${ }^{20}$ (CSAPÓ - TÖRÖCSIK 2020; CSAPÓ - LÖRINCZ 2020) születtek. Nagy átfogó elemzésekre még nem támaszkodhatunk, így a személyes tapasztalatok és elképzelések jelentős súlyt képeznek az értékelésben.

\footnotetext{
${ }^{19}$ https://assets.adac.de/image/upload/v1614344004/ADACeV/KOR/Text/PDF/ADAC_Tourismusstudie_ruwj0c.pdf

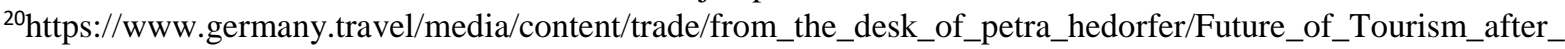
Corona_-_Copenhagen_Institute_for_Futures_Studies_for_ANTOR_-_April_2020_.pdf
} 


\subsection{Trendek, attitüdök}

A korábbi évek jellemző beállítódásaként emlegették a turizmusban a rövidebben, de többszöri utazás $^{21}$ vágyát a turisták részéröl. Ez azt jelentette, hogy a turisták lassan elfelejtik a nagy, egybefüggő - föként a nyári szezonban megvalósuló - több hetes, közös családi üdüléseket és helyette inkább egyéni érdeklődésüknek megfelelve többször, de rövidebbeket utaznak egyedül, vagy párjukkal, barátaikkal ${ }^{22}$.

Ez a trend módosult úgy a pandémia hatására, hogy az utazni vágyók - éppen a korlátozások miatt - kevesebbet, de szintén rövidebben utaznak, de ezek az utak alapvetően az egyéni érdeklődés kielégítését szolgálják. Ez a trend összevetve a fentebb már ismertetett 2020-as adatokkal egyértelműen igazolódni látszik. Ennek hatásaként várható, hogy a kedvenc témák, a kedvenc desztinációk megőrzik piacot irányító szerepüket (pl. kulturális attrakciók és rendezvények, bor- és gasztronómia, aktív turizmus stb.), de vendégek ritkábban érkeznek és kisebb csoportokban, föként kettesével.

A járványügyi korlátozások óvatossá tették az utazókat, akik tartanak az utazásuk közben elrendelt lezárásoktól, vagy az ezt kiváltó romló megbetegedési adatoktól, így utolsó pillanatra tolják a foglalásaikat. A last minute utak eddig is népszerüek voltak, de alapvetően marketing fogásként nyerték meg ezzel a szlogennel az utazni vágyókat az utazásszervezők. Ebben az is benne volt, hogy utolsó pillanatban foglalni egyben árkedvezményt is ígért a turistáknak.

Itt most másról van szó, az utazni vágyók utolsó pillanatig kivárnak a foglalással, hogy ne döntse romba terveiket egy lezárási döntés. Mindemellett az is fontos számukra, hogy a szolgáltató rugalmasan kezelje a foglalásokat és adjon lehetőséget az út, vagy szolgáltatás költségek nélküli visszamondására.

Egészség és higiénia (NTS 2030): a járvány során felértékelődött a higiénia jelentősége a mindennapokban és a turizmusban egyaránt. Az így kialakult új egészségügyi szabályok valószínüleg még sokáig velünk maradnak, valamint a távolságtartás iránti igény középtávon a turizmus ágazatnak is része marad. A következő időszakokban várható, hogy a „biztonságos” területek jelentősen felértékelődnek a turisztikai kereslet szempontjából.

A belföldi úticélok felértékelödése több szempontból is jellemzője a pandémia torzította turizmusnak. Ennek jelentőségét kiválóan jelzi a fentebbi 2. ábra, amely a hazai utazások fellendülését mutatja a korlátozásoktól mentesebb időszakokban. Az okokat és hatásokat elemezve három kérdéskörrel kell foglalkoznunk:

A belföld felértékelődésének elsődleges oka az utazók biztonságra törekvése (BEHRINGER et al. 2021). Biztonság a közelség, ha bármi is történik, a járvány miatt korlátozások lépnek érvénybe, akkor belföldröl még biztosan hazajuthat az utazó. Ennek ellentettje a külföldi út, ahonnan visszajutni nehezebb lehet, átlátni az érvényes szabályokat nehézkesebb. A külföldiek érdeklődését az is erősen visszafogja a pandémiás időszakban, hogy szinte minden ország másképpen szabályozza a belépés és tartózkodás feltételeit.

A második fó érvvé vált a belföldi utaknál, hogy a higiénia és az orvosi ellátás tekintetében magabiztosabb ismereteik vannak az utazóknak belföldön. A szabályok ismerete, a hazai közeg biztonságot sugall.

A harmadik jellemzője a belföldi forgalom fellendülésének az a differenciáltság. A 2020-as nyári szezon nagy tanulsága volt, hogy Budapest forgalmi kieséseit - lehet mondanunk turizmusának összeomlását -, ami a külföldi vendégkör vészes megcsappanásából származott, egyáltalán nem pótolta a belföldi vendégkört remélt megjelenése. A hazai utazók nem tartották

\footnotetext{
${ }^{21}$ https://www.cartourmagazin.hu/igy-utazunk-2020-ban-ime-az-ev-utazasi-trendjei.html

${ }^{22} \mathrm{http}: / /$ www.piskotiistvan.hu/attachments/article/79/VM-7.pdf
} 
elég biztonságos célterületnek a világvárost. Helyette a nyugalmasabb vidéki helyszíneket preferálták, alapvetően a Balatont és a vidéki wellness- és gyógyközpontokat. Az is feltünő változás volt külföldi és belföldi tapasztalatoknál, hogy a nagy kapacitású és tömegesen látogatott helyszíneket némileg kerülték az utazók, így például a korábban nagy forgalmú szállodákat. Helyettük a békésebb, csendesebb panziókat - itthon a falusi szálláshelyeket -, kempingeket preferálták. Ezekben kevesebb a személyes kontaktus, kisebb az esély a megfertőződésre.

Nagyon fontos jellemzője a turistáknak, hogy utazási motivációjuk alig változott ${ }^{23}$. Az igény az utazásra, üdülésre az benne van az emberekben. Aztán, hogy ezt miként realizálják, az az igazi fő kérdés a kínálati oldal szereplői számára.

Fontos megállapítása a vendégkör attitüdjére vonatkozó felméréseknek, hogy a fiatalabb vendégkör szegmensek nagyobb optimizmussal tekintenek a távolabbi utazások felé, ök könnyebben indulnak akár külföldi célpontok felé is. Számukra a repülés még mindig érvényes alternatíva a közlekedésben.

Az érettebb korosztályok óvatosabbak, maradnak az autonómiájukat és önálló mobilitásukat biztosító személygépkocsiknál és az ezekkel elérhető közelebbi úticéloknál.

Az mindenképpen figyelmet érdemel, hogy a világturizmusban meghatározó szerepet játszó német vendégkör (amely számunkra is elsődleges fontosságú) újra úgy szeretne utazni, mint a világjárvány elött. Vissza a jövőbe a jelszavuk, mutatva, hogy az utazási szokások gyökeres átalakulását még a pandémia sem hozhatta létre. Erre utalnak hazai kutatási eredmények is, melyek szerint hosszú távon nem fog érdemben változni a vendégkör utazási habitusa (CSÓKA et al. 2021).

A járvány időlegesen háttérbe tette a 2019-ben még éles vitákat az „overtourism”, vagyis a „túlturizmus”, a tömegturizmus problémáiról. Most új dimenziók tünnek fel a turizmus fenntarthatóságát illetően (környezeti, társadalmi, gazdasági vonatkozásokban egyaránt). Most úgy látszik, hogy a problémák csomópontja a klímavédelem. A globális klímaváltozással szembeni fellépés a turizmus ipar szereplöit és persze a vendégeit sem hagyja érintetlenül. A zöld gondolat, az ökológiai hangsúlyok a szolgáltatóknál erős vonzást gyakorolnak a környezettudatos vendégekre. Belölük pedig egyre több van! A járványválság alatt lecsökkent légiforgalom új lendületet adhat a klímavédelmi törekvéseknek, még jobban elötérbe helyezve a károsanyag-kibocsátás csökkentésének szükségességét és a széleskörü fenntarthatóságot (NTS 2030).

\subsection{Nemzetközi trendek a turizmus szervezés kínálati és marketing területein}

A világjárvány egyrészt felerősített új tendenciákat a közönségkapcsolati módszerek és a vendéglátás, valamint a turizmusmarketing területén; másrészt pedig megmaradtak a korábban megtapasztalt vonulatok, bevált módszerek, amelyeknél kontinuitásról beszélhetünk. Elemzésünkben egyaránt érintjük az új, vagy felújult trendvonalakat és a folyamatosságot jelző tendenciákat.

A pandémia hatása egyértelmüen kimutatható a digitális szolgáltatások ${ }^{24}$ iránti igények felerősödésében. A távolságtartás, a biztonság mellett az online hozzáférhetőség, okos megoldások (smart technológiák ${ }^{25}$ ) igazi felértékelődését hozta a COVID-19.

\footnotetext{
${ }^{23}$ https://assets.adac.de/image/upload/v1614344004/ADAC-

eV/KOR/Text/PDF/ADAC_Tourismusstudie_ruwj0c.pdf

${ }^{24} \mathrm{https}$ ://www.expat-news.com/events-fuer-expats-auswanderer/diese-7-tourismus-trends-sieht-die-branchefuer-die-zukunft-des-reisens-47134

${ }^{25} \mathrm{https}$ ///www.tourism-review.com/next-years-tourism-trends-news11768
} 
A hagyományos, ügyfélközpontú szolgáltatások átalakításra kerültek, köszönhetően a technológia által támogatott lehetőségek szélesebb körü használatának, mint például a mobil bejelentkezés, az érintésmentes fizetés, hangvezérlés és biometria. Azok a fogyasztók, akik már megszokták, hogy arc- és ujjlenyomat-felismeréssel oldják fel okostelefonjuk és laptopjuk feloldását, hamarosan ugyanilyen kényelmet várnak el szállodai szobáik elérésében is.

A vendégek számára lehetővé kell tenni az online információszerzés minél több csatornáját. Már nem elégedhet meg a szolgáltató a saját weboldallal, hanem a közösségi oldalakon (Facebook, Twitter, Instagram stb.) is meg kell jelennie és aktívnak kell lennie. A vendégkör jelentős része a „social media” felületekről szerzi be az utazási döntéséhez szükséges értékelt információkat. Ezek a mások véleményét tükröző információk lassan már belépnek a korábban meghatározó rokon, ismerős, barát, munkatárs ajánlásai elé a döntést megalapozó véleményeknél.

Az online megjelenés azonnali foglalási lehetőség és perceken belüli visszaigazolás nélkül mit sem ér! A szolgáltatások összehasonlíthatósága és a lemondási garanciák miatt az OTA-k (Online Travel Agency) szerepe tovább erősödött. Arányuk a szállásfoglalásokban (booking.com; szállás.hu stb.) már közelíti a 80\%-ot. Komoly küzdelem - mondhatni utóvédharc - figyelhető meg a szálláshelyek és szolgáltatók saját online rendszerei és a globális piac OTA-i között. A trendek és arányok egyértelműen a globális foglalási rendszerek súlyának erösödését jelzik elöre.

A digitális technológiák alkalmazása a turizmus marketingben és az utazási élmény előkészítésében, majd megerősítésében a virtuális valóság (VR: Virtual Reality) és a kiterjesztett valóság (AR: Augmented Reality) egyre szélesebb körü használatát követeli meg ${ }^{26}$. Ez alapvetően desztinációmarketing szintjén jelenik meg, egy-egy célterület promóciójában és a helyi élmények kiterjesztésében ${ }^{27}$. Ezek a technológiák részben még az utazás kiváltására is alkalmasak egészségügyi veszélyhelyzetekben, a megismert lezárások idején ${ }^{28}$.

A szállodai müködés digitális fejlesztése egyre inkább kiterjed az ügyfélkapcsolatok, a kommunikációs csatornák és a hírnév felügyeletére. Ezt valósítják meg a mobil, felhőalapú és integrált megoldások, például az automatizált üzenetküldés, a prediktív elemzések, az ügyfélprofilozás.

A vendégek éppen a digitális megoldások révén szólíthatók meg személyesen. Az ehhez szükséges, egyénhez kötődő információkat a korábbi tartózkodáshoz kötődő adatokból válogathatja ki a szolgáltató.

A sharing economy, a megosztáson alapuló gazdaság gyors terjedése drasztikus átalakulást eredményezett több területen, mint például a szálláshely-szolgáltatásban vagy személyszállításban is (NTS 2030). Ezek a változások várhatóan a mindennapi élet részei maradnak, újabb üzleti modellekké fejlödhetnek, amelyek pedig jelentős hatással lesznek a turizmus ágazatra is. Az Airbnb a nagyvárosokban és kiemelt desztinációkban már a szállodaipar érdekeit veszélyezteti, hazai szabályozást éppen a pandémia időszakában szigorították ${ }^{29}$.

A vendégkör túljutva a pandémia hullámain részben megőrizte korábbi motivációit, részben levonta maga számára a tanulságokat. Mindenképpen változott szemléletmódjában, így

\footnotetext{
${ }^{26} \mathrm{https}$ //Www.tourlane.de/umfrage-reisetrends/

${ }^{27} \mathrm{https}$ ://www.tui-berlin.de/top-5-reisetrends-2021/

${ }^{28} \mathrm{https}: / / \mathrm{ktk} . p t e . h u /$ sites/ktk.pte.hu/files/images/tudomany/rendezvenyek/fogyasztas/efop_generaciok_alaptanul many_turizmus_2018_0.pdf

${ }^{29} 2020$. évi XCVI. törvény a rövid távú szálláshelykiadással összefüggő egyes törvények módosításáról
} 
elérésük érdekében a nekik szóló üzeneteknek is tekintettel kell lenniük a módosult megközelítésekre.

A pandémia alatt felerősödött mondás jelzi az utazók motivációinak változását: ,, $a$ kevesebb több”. Az utazók egyre kevésbé keresik a gazdagság pazar megjelenítését, inkább bölcsen, célirányosan költenek, és ezzel remélik, hogy pozitív hatást gyakorolnak a világra. Az egyedi élmények, amelyek a helyi közösségekkel való kapcsolatépítésből, beilleszkedésből fakadnak, nagyon megbecsült utazási tapasztalatnak minősülnek.

Az értékrendek és magatartási szabályok változásának egyik jele, hogy a fellépő veszélytényezőkre válaszul sokan felismerték azt a meditatív értéket, hogy egyedül töltsék az időt, és szemlélődve a világban kapcsolatokat építsenek és barátokat szerezzenek. Az egyedül utazók kedvében járva a vendéglátóhelyek és szálláshelyek törekszenek a vendégekkel való személyes bánásmód erősítésére, az otthonosság körülményeinek a megteremtésére. Ebben a vonulatban a szolgáltatók súlyt helyeznek arra, hogy a vendégek és a helyiek közötti különbség mérséklődjön, az érkező megélhesse a közösségbe illeszkedés élményét (GONDA et al. 2019).

A XXI. század nagy kihívásai közé tartozó környezeti kérdések, mint a fenntarthatóság és a klímavédelem iránti affinitásnak meg kell jelennie a szolgáltatói oldalon is. Ennek jelei az ökológiailag tudatos, környezetkímélő üzemeltetés, a társadalmi és környezeti felelősségvállalás ${ }^{30}$. Aprónak látszó, de fontos jelzések a közönség felé, hogy az egyszer használatos mủanyagok használatát kerülik, a digitális technológiáknak köszönhetően megszünik a felesleges papírfogyasztás. Törekszenek az élelmiszer-pazarlás csökkentésére. A vendéglátás menedzsmentjében meghozott döntéseket etikai és környezetvédelmi szempontok szerint alakítják. Mindezek a szempontok végigkövetik a szolgáltatások létrehozásától, azok müködtetésén és felújításán át a teljes rendszert. Ezen megoldások megismertetése a vendégekkel egyrészt jelzi az elköteleződést a fenntarthatóság és a környezetvédelem iránt, másrészt edukatív jellegü a téma iránt érzékeny vendégkör számára (SZABÓ et al. 2017).

\section{A hazai fejlesztéspolitika új irányai és ezek várható hatásai Dél-Baranya turizmus perspektíváira}

A hazai turizmus fejlesztéspolitika alapdokumentuma a Nemzeti Turizmusfejlesztési Stratégia NTS 2030, ami 2017-ben került elfogadásra. A stratégiára alapozva szabályozta a kormányzat a turisztikai térségeket ${ }^{31} 2020$. őszén. A fejlesztésre kijelölt 11 turisztikai térség közé tartozik a Pécs-Villány turisztikai térség is (3. ábra). Az ábrán - megtévesztő módon - egy igen széles övezetként jelenik meg a Pécs-Villány turisztikai térség, ami szinte egész Baranyát magába foglalja. Az ábra alsó részén jól látszik azonban, hogy a turisztikai térségbe a hivatkozott rendelet szerint csak 22 település tartozik bele és a térség két területre szakad szét a Mecsek és a Villányi-hegység környezetében. Ezek a települések a megyének csak egy igen kicsi részét fedik le.

\footnotetext{
${ }^{30} \mathrm{https} / / /$ www.marcopolo.de/reise-reportagen/detail/die-grossen-tourismus-trends-ab-2021.html

31 429/2020. (IX. 14.) számú kormányrendelet a turisztikai térségek meghatározásáról
} 


\section{3. ábra:A Pécs-Villány turisztikai térség}

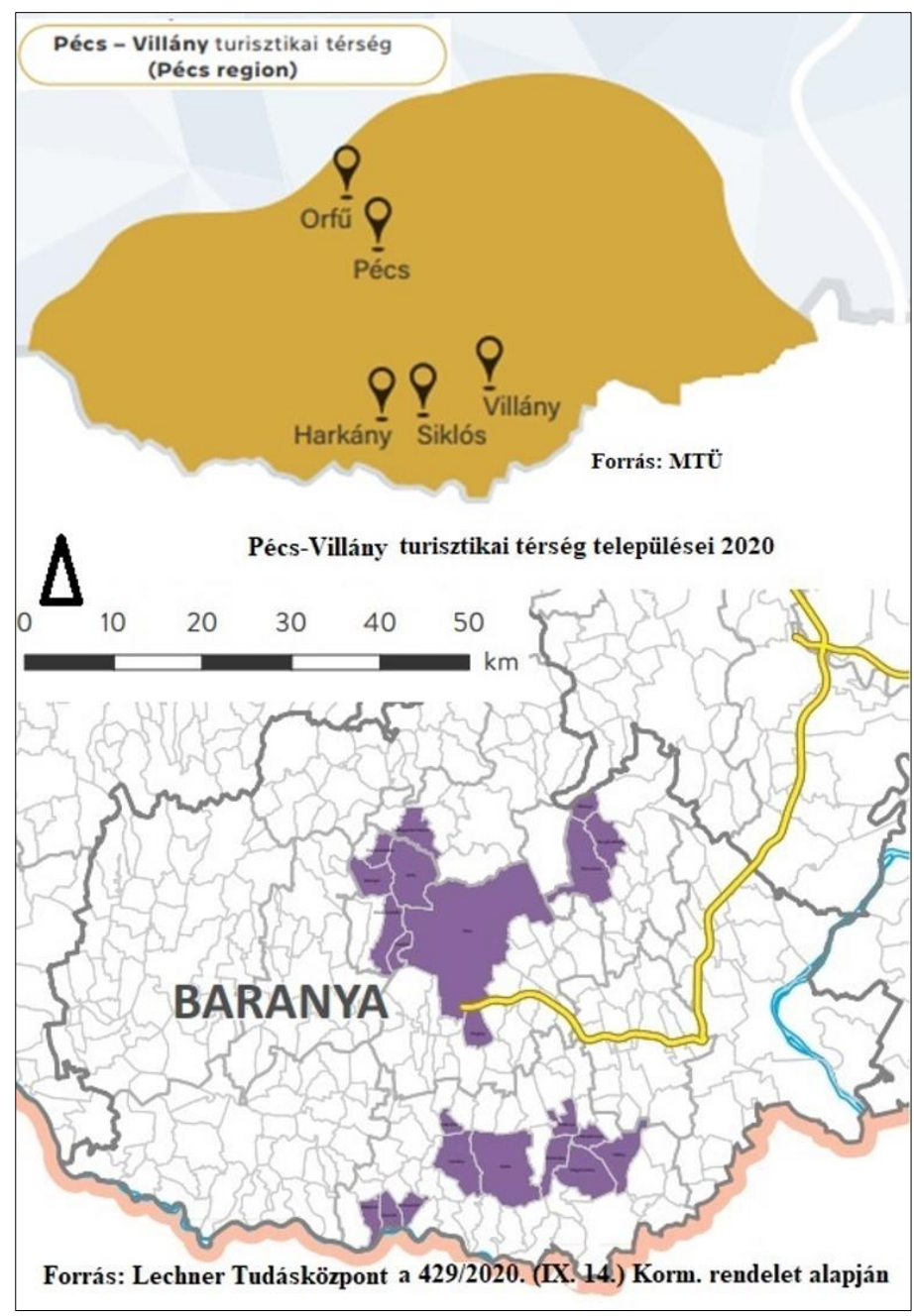

Dél-Baranyából csak a 4. ábrán jelölt települések tekinthetők a turisztikai térség részének. Ezek a turisztikai szempontból igen frekventált települések a Villányi borvidék keleti részén helyezkednek el Villány, Villánykövesd, Palkonya és Nagyharsány, Siklós Harkány környezetében. Hozzájuk még három drávamenti falu csatlakozik Szaporca környékén. Ez egy szükebb metszet a dél-baranyai térségböl, bár a remények szerint ezek turisztikai fejlesztése húzza majd magával a többi, a térségbe tartozó települést is. 
4. ábra: A Pécs-Villány turisztikai térség települései Dél-Baranyában

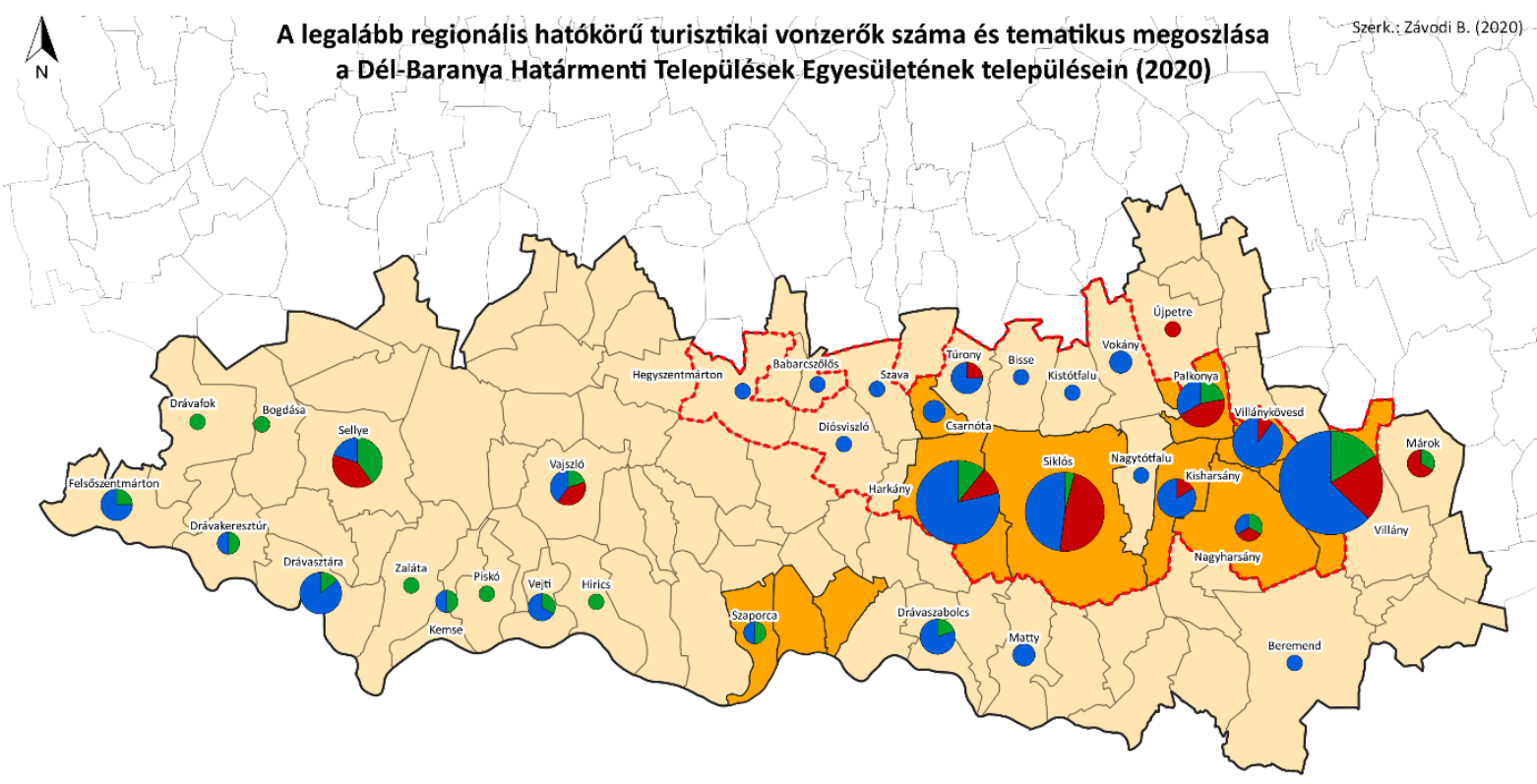

$\quad 7,5 \quad 15 \mathrm{~km}$

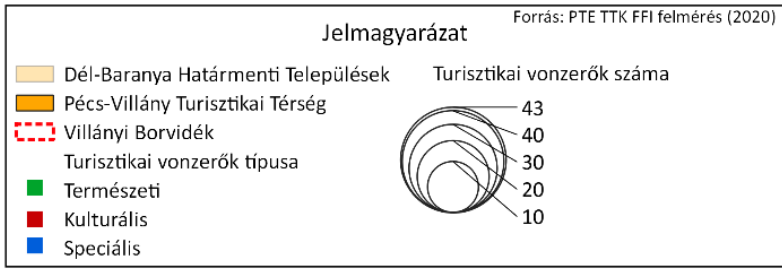

Forrás: SZABÓ et al. 2021

Az NTS 2030 stratégiát a Turizmus 2.0 fejezettel 2021 tavaszán frissítette a Magyar Turisztikai Ügynökség. A frissítés célja a stratégia fejlesztési irányainak a konkretizálása, különös tekintettel a világjárvány hatásaira és kihívásaira. A stratégia, alapvetően desztináció (turisztikai térség) központú megközelítése mellett, négy termékkörben (vendéglátás, egészségturizmus, MICE szegmens és vallási turizmus) és a hozzájuk kapcsolódó menedzsment tevékenységek (marketing és értékesítés) vonatkozásában elemezte a turisztikai pozíciókat és határozta meg a fejlesztési irányokat.

A stratégia és annak frissített változata alapjaiban határozza meg a hazai, turizmusra vonatkozó fejlesztéspolitikát, ezért meghatározó a jelentősége a dél-baranyai területre is. Elemzésünk kitér első körben a turisztikai térség helyzetét érintő megállapításokra a stratégiában, majd a második értékelési szinten a tervezett fejlesztésekhez való kapcsolódást mutatjuk be Dél-Baranya szempontjából.

\subsection{Dél-Baranya turisztikai pozíciója az NTS 2030 szemszögéböl}

A 2020. szeptemberében nevesített 11 turisztikai térség között találjuk a Pécs-Villány turisztikai térséget, melyről az MTÜ egy összefoglaló elemzést készített. Az elemzésből azokat a részeket emeltük ki, amelyek Dél-Baranya turisztikai pozíciójára releváns információkat tartalmaztak $^{32}$.

A Pécs-Villány desztináció az ország klasszikus vendégfogadó területei közé tartozik, a vendégfogadás itt valóban évszázados hagyományokon alapul. Harkány 200 éve müködő gyógyfürdőjét már a 19. század végétől kezdve szívesen keresték fel a gyógyulni vágyók, a

\footnotetext{
${ }^{32}$ https://mtu.gov.hu/cikkek/pecs-villany-turisztikai-terseg-1927
} 
villányi (borvidéki) turizmus alapjait pedig a vendégfogadásra berendezkedett, rendezett sváb falvak teremtették meg, amelyet az 1990-es évek elején a vállalkozóvá vált nyitott és tehetséges borászok összefogása és magas színvonalú szolgáltatásai emeltek országos hírüvé.

A hivatkozott szakanyag meghatározta a térség vendégforgalma általános hanyatlásában fontos tényezőket:

- $\quad$ a délszláv háború hatásai, amelynek okán az utazók évekig nem tartották biztonságot úti célnak a térséget,

az elmaradt célzott turisztikai fejlesztések kiegészülve a turizmusban nélkülözhetetlen szakmai-menedzsmenti-értékesítési tudás részbeni hiányával (az uniós fejlesztési források elaprózódása, a meghatározó szálláshelyfejlesztések hiánya),

a desztináció gazdasági perifériára való kerülése, amely miatt a Budapesten kívüli fó küldőterületet jelentő lakosság (Baranya, Tolna és Dél-Somogy) elvándorlása is számottevővé vált (és tart ma is).

Miközben az ország más vidéki térségeit jelentős attrakciós fejlesztések (új fürdökomplexumok kialakítása és meglévők jelentős fejlesztése, a meglévő turisztikai attrakciók - várak, kastélyok, egyházi örökség - turisztikai attraktivitásának megerösítése, családokat fogadó kalandparkok létrehozása stb.), emblematikus szállodaépítések jellemezték, a Pécs-Villány desztináció turisztikai kínálata - kevés üdítő kivételtől eltekintve - a rendszerváltozás utáni szinten rekedt meg.

Pedig a desztinációs termékalap megfelelő alapot jelentett volna a fejlesztésekre. Most csak a dél-baranyai térségre koncentrálva kimondható, hogy Villány Péccsel összevetve az ország azon kevés területei közé tartozik, amely „kitalálta és megvalósította önmagát” különösebb központi beavatkozás nélkül. Tokajjal ellentétben a borvidéket nem a borok, hanem a neves és „jó arc" borászok és borászatok tették szorgalmas munkával országosan ismertté (Bock, Gere, Tiffán, Polgár, Günzer, Sauska, Vylyan, stb.). A hagyományos borkóstolás mellé kínált tájjellegü gasztronómiával (sváb ételek - stifolder, gőzgombóc, strudel), falusi vendégfogadással, majd később az országban először a „borwellness” szolgáltatásainak megteremtésével (Crocus Gere Borhotel, Bock Hotel Ermitage) a borvidék nemzetközi hírüvé és vonzású vált.

Az MTÜ értékelése szerint a térség turisztikai szuprastruktúrája (szálláshelyek és vendéglátóhelyek), szolgáltatási minősége az előzőekben kiemelt, kis kapacitású szállodákon túl maximum közepes színvonalúnak tekinthető, és kevés kivételtől eltekintve hasonló minőség jellemzi a vendéglátóhelyeket is; magas költési hajlandóságú vendégkör megszólítására Villány kivételével a desztináció ma nem alkalmas.

A hivatkozott szakanyag alapján kimondható, hogy a határmenti földrajzi elhelyezkedés ellenére a külföldi vendégforgalom térségi teljesítményből történő részesedése nem éri el az országos átlagot, sőt egyre csökkenő arány jellemzi. A két legfőbb küldő terület két különböző helyszínen, a német vendégkör Villányban és a borvidék sváb hagyományú településein (döntően idősebb, szenior vendégek), a cseh fürdőgyógyászati szolgáltatások iránt érdeklődő szegmens pedig Harkányban (a nyugat-magyarországi fürdőtelepülésekhez képest egyébként koránt sem számottevő volumenben és alacsonyabb igényszinttel) jelenik meg. A lokáció okán elviekben elérhető horvát vendégkör megjelenése maximum napi látogatásokban merül ki Harkányfürdő szintjén.

Az értékelés szerint a desztináció (Pécs-Villány) értékesíthetőségét alapvetően a két, kifejezetten a magas minőség élményígéretét (,magas kultúra - prémium borok”) hordozó 
termék biztosítja, ahol a dél-baranyai térséget alapvetően a bor és gasztronómia adja az országosan ismert és prémium borélményt kiváló borászataival.

Harkány helyzetére külön kitér az MTÜ szakmai elemzése, hiszen pozíciója és perspektívái kulcskérdésnek számítanak Dél-Baranya turizmusa szempontjából. Az országos pozicionálás során az egészségturisztikai profillal márkázni kívánt desztinációkhoz képest (Bük-Sárvár, Gyula és térsége, Szeged-Makó) a fürdőtelepülés nem kaphat kiemelt szerepet, ugyanakkor az országos termékstruktúrában elért pozícióját illetően az egyedi gyógyászati profilt (psoriasis és meddőségi kezelések) szükséges kiemelni és termékfejlesztéssel megerősíteni. A szakmai elemzés szerint Harkány esetében első körben a lokális kereslet megerősítése szükséges (és csak azt követheti az országos majd nemzetközi), a Baranya megyei (és potenciális küldőpiacot jelentő Tolna megyei) fürdőmotivációjú vendégek ma Harkány helyett szívesebben veszik igénybe a Szeged-Makó térség fürdőit. Ehhez a település és a szolgáltatók új alapokra helyezett

együttmüködése szükséges. A versenyképességben lemaradt Harkány-termék ezzel tud középtávon a desztinációs vízióhoz hozzájárulni.

A térség jelenlegi keresletére tett megállapítások az értékelő tanulmányban hangsúlyozzák, hogy csak a vendégéjszakák ötöde származik beutazó turizmusból, ezeknek a fele cseh és német turistákhoz köthető. A térség célcsoportja a kulturális céllal utazó, magas minőségü bor és kultúra iránt érdeklődő fiatal párok és társaságok, valamint szenior párok, ez utóbbiakat a magasabb fizetési hajlandóságúak közé sorolja. A jövő szempontjából a kitörési pont lehet a villányi borvidék nemzetközi piacokon történő pozícionálása, egy szinten a villányi borral (Villányi Franc), a kulcs a főszezonon kívüli aktivitás promotálása.

A folytatandó marketing tevékenység szempontjából az NTS 2030 - Turizmus 2.0 - az alábbiakat határozta meg: A német szegmensek által már jelenleg is viszonylag ismert desztináció tovább népszerüsíthető kulturális értékajánlatánál fogva pl. a német „Kozmopolita fiatalok" körében, vagy a bor- és gasztro értékajánlattal az erre fogékony szegmensek felé.

\subsubsection{A vendéglátás termékcsoport fejlesztési irányai a Pécs-Villány, ezen belül a Dél-Baranya térség számára}

A frissített turizmus stratégia (NTS 2030 Turizmus 2.0) külön meghatározta a vendéglátásgasztronómiai szakterületre vonatkozó fejlesztési elképzeléseket. Ezek szerint a villányi borvidék nemzetközi piacokon történő pozícionálására jó lehetőséget biztosít az eredetvédelmi rendszer (kikerics védjegy) és a magyarországi borvidékek közül elsőként kialakított VillánySiklósi Borút. A régió gasztronómiai kínálatának ehhez igazodóan nagy hangsúlyt ajánlott fektetni a borok és ételek párosítására, a prémium pozícionálásra, a helyi, hagyományos ízek és a sváb kulturális jegyek bemutatásával. A régió minden év őszén megrendezett borünnepeként definiálta a Villányi Vörösbor Fesztivál, amely pincelátogatásokkal, borkóstolókkal és változatos kulturális programokkal várja a látogatókat. Továbbfejlesztési lehetőség lehet a környékbeli vendéglátóhelyek bekapcsolódása speciális, borsorokhoz igazított menük kialakítása által.

Ezt a fejlesztési irányt erősítheti a Villányi borvidék 2021 őszén bevezetett helyi termék minősítési és védjegy rendszere.

\subsubsection{Az egészségturizmus helyzete a térség fürdötelepülésein}

A frissített stratégia elvégezte a hazai gyógyhelyek és fürdőtelepülések kategorizálását a jelenlegi helyzetük és fejlesztési perspektíváik alapján. A dél-baranyai térségből Harkány és Siklós került bele a kategorizálásba.

Harkány nemzetközi regionális hatókörü, meghatározó egészségturisztikai település besorolást kapott. A kategória azt jelenti, hogy olyan meghatározó egészségturisztikai kínálattal 
rendelkező települések (azon belül attrakciók), amelyek meglátogatásakor a turista fó úti célja az egészségturisztikai kínálat megismerése, szolgáltatások igénybevétele, ugyanakkor nem generál a térség attrakcióiban és szálláshelyeink további vendégszámot. Azonban az egészségturizmus miatt további extra időt hajlandó eltölteni a településen, ami a térségi vendégéjszakák számának növekedésében is megmutatkozik. Mindez kiegészül a nemzetközi regionális hatókörrel, ami olyan egészségturisztikai kínálattal rendelkező településekre jellemző, amelyek belföldi látogatókon túl elsősorban a közeli - autóval, busszal vagy vonattal elérhető - nemzetközi küldőpiacok (szomszédos országok, továbbá Lengyelország, Csehország és Németország) megszólítására alkalmasak. Harkány ezzel a besorolással az egészségturisztikai zászlóshajók és nemzetközi vonzású fürdők, mint pl. Hévíz, Debrecen, Hajdúszoboszló mögötti kategóriába került.

Siklós az országos, meghatározó egészségturisztikai település kategóriába sorolódott. Ez pedig azt jelenti, hogy olyan egészségturisztikai kínálattal rendelkező települések közé tagolódik, amelyek alkalmasak arra, hogy az ország egész területéről és a határközeli térségekből érkező turisták számára megfelelő utazási motivációként szolgáljanak; felkeresésük érdekében a turisták 3 óránál rövidebb utazási időt vállalnak. Ez a besorolás szerint egy hazai szinten közép kategóriás szintet jelöl.

A Pécs-Villány turisztikai térség a két Dél-Baranyát reprezentáló fürdő mellett csak a térségi hatókörü Magyarhertelendi fürdővel jelenik meg a hazai egészségturisztikai kínálatban. Az is figyelmet érdemel, hogy a 11 turisztikai térség közül hétben van egy, vagy akár több zászlóshajónak minősített egészségturisztikai település, de ebben a körben a térség nem kapott helyet!

A MICE szegmensben a stratégia konkrét érintettséget nem határozott meg a térség számára.

\subsubsection{A vallásturizmus termékcsoport}

A zászlóshajó meghatározású vallásturisztikai centrumok közé (országosan tíz lett megnevezve) a Pécs-Villány turisztikai térségből csak a Pécs - Szent Péter és Pál Apostolok székesegyház került be. A dél-baranyai térség és így Siklós-Máriagyüd nem tartozik ebbe a kiemelt vallásturizmus körbe.

\section{Következtetések}

A COVID-19 világjárvány teljesen váratlanul tört rá a világra, egyelöre még alig felmérhető károkat okozva az élet valamennyi területén. Abban azért egyetértés van az elemzők részéről, hogy a turizmus és a hozzá szorosan kötődő vendéglátás a legnagyobb vesztesek közé tartozik. A járvány okozta veszélyeztetettség és a megfékezésére hozott korlátozások még két évvel a kitörése után is erösen befolyásolják a lakosság és természetesen az utazók, a vendégek mindennapjait. Az utazási, üdülési szokások igen gyorsan és jelentősen átformálódtak, amely globális turizmus mellett minden desztinációra figyelembe veendő hatást jelent. Ez nem lehet másképpen a hazai turisztikai térségek közé tartozó Dél-Baranyában sem. Az általános keresleti és kínálati trendek gyors változásai okozta kihívásokra ennek a turisztikai célterületnek is válaszolnia kell!

Kedvezőnek tekinthető, hogy a belföld egyértelmüen preferált célterületté vált a pandémia hullámai közötti „,szabadabb” időszakokban. A nagyhírủ és jelentős vonzású termékek mellett a kicsi, szétszórt, vidéki jellegü kínálatok felértékelődtek, amely egy változatos vonzeröösszetételü és rurális jellegü térségnek előnyöket kínál. Ugyanígy az egyéni igények hangsúlyozódása és a tömegesség kerülése is kedvező esélyt teremt a térség számára. 
Mindezek realizálása megköveteli a térségtől, hogy legyen affinitása a változó, digitális kihívást jelentő fogyasztói igényekre, az életstílus változására, a környezettudatosság és az egészségvédelem, valamint a biztonság előtérbe kerülésére.

A turizmusfejlesztés szempontjából nem tekinthető kedvezőnek, hogy a dél-baranyai térségből csak néhány település került bele a Pécs-Villány turisztikai térségbe és ezek a preferált települések is a térség keleti részére koncentrálódnak. Szintén rossz indulási pozíciót jelez az, hogy a Nemzeti Turizmusfejlesztési Stratégiában (NTS 2030) csak igen szük termékszegmensekben tekintik erőteljesnek a dél-baranyai kínálatot. A boron, a gasztronómián kívül csak a vidéki tradíciókkal és második vonalba tartozó egészségturizmussal számolnak nemzetközi és országos szinten. Olyan fontos szegmensekben, mint a MICE és a vallásturizmus, még országos hatókörrel sem rendelkezik a terület.

A sikeres és reális jövőképben meg kell jelennie a turizmus trendek változásaira adandó válaszoknak és a hazai fejlesztéspolitika adta keretek kihasználásának és lehetőség szerinti bővítésének. Mindezekben a belföldi vendégkör 2020. és 2021. év nyarán tapasztalt jelentős kereslete esélyt adhat.

\section{Irodalomjegyzék}

AUBERT, A. - SZABÓ, G. - JÓNÁS-BERKI, M. - HORVÁTH, A. - SZEIDL, K. KOCSOR, ZS. - RAFFAY, Z. (2018a): New Directions and Solutions in Ecotourism in Hungary. In: Danko, Simic; Judith, Pizzera; Wolfgang, Fischer (szerk.) Spatial Tensions Future Changes $=$ Räumliche Spannungen - Zukünftige Chancen Graz, Ausztria : Institut für Geographie und Raumforschung, Karl-Franzens-Universität Graz 140 p. pp. 71-82. , 12 p.

AUBERT, A. - CSAPÓ, J. - GYURICZA, L. - JÓNÁS-BERKI, M. - PÁLFI, A. - SZABÓ, G. (2018b): Szociálgeográfiai szempontok a turisztikai trendek értelmezésében. In: Pap, N; Szalai, G (szerk.) Táj geográfus ecsettel, Pécs, Magyarország : Pécsi Tudományegyetem Természettudományi Kar (PTE TTK) 310 p. pp. 193-218. , 26 p.

AUBERT, A. - MARTON, G. - SZABÓ, G. (2011): A Dél-Dunántúli Turisztikai Régió. In: Dávid, Lóránt; Remenyik, Bulcsú (szerk.) A Kárpát-Pannon térség turizmusföldrajza Gyöngyös, Magyarország : Károly Róbert Föiskola (KRF342 p. pp. 137-157. 21 p.

AUBERT, A. - CSAPÓ, J. - PIRKHOFFER, E. - PUCZKÓ, L. - SZABÓ, G. (2010): A method for complex spatial delimitation of tourism destinations in South Transdanubia. HUNGARIAN GEOGRAPHICAL BULLETIN (2009-) $59: 3$ pp. 271-287. 17 p.

AUBERT, A. - SZABÓ, G. (2008): Tourism Geographical Interpretation os Complex Spatial Categories. In: Lóczy, D; Tóth, J; Trócsányi, A (szerk.) Progress in Geography in the European Capital of Culture 2010 Pécs, Magyarország: Imedias Kiadó 335 p. pp. 149-160. 12 p.

AUBERT, A. - SZABÓ, G. (2007): Turizmus kutatás és tervezés egy határmenti régióban: DélDunántúl. In: Szónokyné, Ancsin G (szerk.) Határok és Eurorégiók: Nemzetközi Földrajzi Tudományos Konferencia Szeged, Magyarország: Szegedi Tudományegyetem Természettudományi Kar Gazdaság- és Társadalomföldrajz Tanszék 581 p. pp. 475-481. 7 p.

AUBERT, A. - SZABÓ, G. (2005): Baranya Megye Turizmusfejlesztési Stratégiája. Pécs, Magyarország : Temporg Kiadó

AUBERT, A. - MISZLER, M. - SZABÓ, G. (2000): Baranya megye turizmusmarketing terve. Pécs, Magyarország: Baranya Megyei Kulturális és Idegenforgalmi Központ, 66 p.

AUBERT, A. - SZABÓ, G. (1999): Differenciált turizmusfejlesztés Baranya megye példáján (megyei önkormányzat és a turizmus). TURIZMUS BULLETIN 3(1) pp. 24-30. 7 p. 
AUBERT, A. - SZABÓ, G. (1993): A falusi turizmus újrainditásának és fejlesztésének lehetöségei Baranya megye két eltérő adottságú településcsoportjában. Pécs, Magyarország: MTA Regionális Kutatások Központja (MTA RKK), 65 p.

BEHRINGER, ZS. - TEVELY, T. - BUDAVÁRI, B. - HINEK, M. (2021): Utazás a pandémia árnyékában - avagy hogyan változnak a magyar lakosság utazási szokásai, illetve fogyasztói döntései a világjárvány idején. TURISZTIKAI ÉS VIDÉKFEJLESZTÉSI TANULMÁNYOK 6(4) pp. 101-114.

CSAPÓ, J. - LÖRINCZ, K. (2020): A turizmus gazdaságban betöltött szerepének és irányainak bemutatása Magyarországon a COVID-19 elött és után. Geometodika, 4(3).

CSAPÓ, J. - TÖRÖCSIK, M. (2020): A turizmus jövője, a nemzetközi és hazai turizmus legújabb trendjeinek elemzése elméleti és gyakorlati megközelitésben. PTE KTK Pécs. https://pea.lib.pte.hu/bitstream/handle/pea/23854/csapo-torocsik-a-turizmus-jovoje-anemzetkozi-es-hazai-turizmus-legujabb-trendjeinek-elemzese-elmeleti-es-gyakorlatimegkozelitesben-PTE-KTK-2020.pdf?sequence=1\&isAllowed=y

CSAPÓ, J. - GERDESICS, V. - GONDA, T. - RAFFAY, Z. - TÖRÖCSIK, M. (2018): Turizmus, a magyar lakosság turizmussal kapcsolatos beállitódása generációs szemléletü vizsgálattal.

https://ktk.pte.hu/sites/ktk.pte.hu/files/images/tudomany/rendezvenyek/fogyasztas/efop_gener aciok_alaptanulmany_turizmus_2018_0.pdf

CSAPÓ, J. - AUBERT, A. - SZABÓ, G. (2015): Recreational and tourism-purpose mobility along border regions: the South Transdanubian (Hungary) case. In: Hungarian, Geographical Society (szerk.) EG EUGEO Budapest: Congress Programme and Abstracts Budapest, Magyarország : Hungarian Geographical Society 263 p. p. 92

CSÓKA, L. - PAIC, R. - PRISZTÓKA, GY. - VARGÁNÉ SZ. K. - VARGA, T. - MARTON, G. (2021): A hazai utazási szokások változásai a koronavírus-járvány hatására. TURISZTIKAI ÉS VIDÉKFEJLESZTÉSI TANULMÁNYOK 6(4) pp. 16-27.

GONDA, T. - NAGY, D. - RAFFAY, Z. (2019): The impact of tourism on the quality of life and happiness. Interdisciplinary Management Research/Interdisziplinare Managementforschung 15, pp. 1790-1803

KOVÁCS, L. - KELLER, K. - TÓTH-KASZÁS, N. - SZÖKE, V. (2021): A Covid19-járvány hatása egyes turisztikai szolgáltatók müködésére: azonnali válaszok és megoldások. TURISZTIKAI ÉS VIDÉKFEJLESZTÉSI TANULMÁNYOK 6(2) pp. 6-24. 19 p.

MCKINSEY \& COMPANY (2020): COVID-19: Briefing Materials. Global Health and Crisis Response, 2020. McKinsey \& Company, 1 June.

POSGAY, I. - REGÖS, G. - HORVÁTH, D. - MOLNÁR, D. (2020): A koronavírus-járvány gazdasági hatásairól. Polgári Szemle, 16. évf. 4-6. szám, 2020, 31-50., DOI: 10.24307/psz. 2020.1004

POSGAY, I. - REGŐS, G. - HORVÁTH, D. - MOLNÁR, D. (2019): Fejezetek a hiszterézisre vonatkozó közgazdasági elméletekböl. Pénzügyi Szemle, 64. évf., 3. sz., 419-436, https://doi.org/10.35551/psz_2019_3_6

SZABÓ, G. - ZÁVODI, B. - SASS, E. (2021): A helyi termékek szerepe és lehetőségei a turizmusban $=$ THE ROLE AND POTENTIAL OF LOCAL PRODUCTS IN TOURISM In: Mókusné, Pálfi Andrea; Nod, Gabriella (szerk.) Interregionális kutatási eredmények a turizmusban : örökségvédelem, intézményrendszer, helyi termékek (Hun-Au-Slo-Ukr) Pécs, Magyarország : PTE TTK FFI Turizmus Tanszék (2021) 130 p. pp. 91-110. , 20 p. 
SZABÓ, G. - CSAPÓ, J. - MARTON, G. (2017): Zöldutak a turizmusban - Innováció és jó gyakorlat a szelíd turizmusban. Földrajzi Közlemények, 141(2), pp. 152-163.

SZABÓ, G. - AUBERT, A. (2012): A turizmus és a bormarketing kapcsolata a Pannon Borrégióban. In: Kuráth, Gabriella (szerk.) Mandulavirágzási Tudományos Napok 2012 Pécs, Magyarország: Pécsi Tudományegyetem 322 p. pp. 45-53. 9 p.

SZABÓ, G. - AUBERT, A. (2005): La situación de las profesiones y formaciones relacionadas con el patrimonio y las posibilidades de la formación en gestión de patrimonio. ABACO: REVISTA DE CULTURAL Y CIENCIAS SOCIALES 46 pp. 49-56. 8 p.

Állami Számvevőszék elemzése: A turizmus helyzete - a járvány előtt és alatt file:///C:/Users/Otthon/Downloads/turizmus_jarvany20210325.pdf

429/2020. (IX. 14.) számú kormányrendelet a turisztikai térségek meghatározásáról

Nemzeti Turizmusfejlesztési Stratégia 2030 - Turizmus 2.0 https://mtu.gov.hu/cikkek/strategia 2020. évi XCVI. törvény a rövid távú szálláshelykiadással összefüggő egyes törvények módosításáról.

\section{Internetes források}

https://www.unwto.org/news/tourist-numbers-down-83-but-confidence-slowly-rising

https://assets.adac.de/image/upload/v1614344004/ADAC-

e/KOR/Text/PDF/ADAC_Tourismusstudie_ruwj0c.pdf

https://www.adac.de/verkehr/standpunkte-studien/mobilitaets-trends/tourismusstudie-reisencorona/https://mtu.gov.hu/cikkek/strategia

https://mtu.gov.hu/cikkek/pecs-villany-turisztikai-terseg-1927

https://www.expat-news.com/events-fuer-expats-auswanderer/diese-7-tourismus-trends-siehtdie-branche-fuer-die-zukunft-des-reisens-47134

https://www.marcopolo.de/reise-reportagen/detail/die-grossen-tourismus-trends-ab-2021.html https://www.tourlane.de/umfrage-reisetrends/

https://www.tui-berlin.de/top-5-reisetrends-2021/

https://www.tourism-review.com/next-years-tourism-trends-news11768

https://www.germany.travel/media/content/trade/from_the_desk_of_petra_hedorfer/Future_of _Tourism_after_Corona_- Copenhagen_Institute_for_Futures_Studies_for_ANTOR__April_2020_.pdf

http://www.piskotiistvan.hu/attachments/article/79/VM-7.pdf

https://www.cartourmagazin.hu/igy-utazunk-2020-ban-ime-az-ev-utazasi-trendjei.html 